\title{
Sowing a 'culture of conviction': what shall domestic criminal justice systems reap from coercive human rights?
}

\author{
Mattia Pinto* \\ "They that sow the wind, shall reap the whirlwind" (Hosea 8:7)
}

\section{Introduction}

In general, we tend to think of human rights bodies as moderating and restraining state penal policies. These institutions appear to have 'humanised' criminal justice, by upholding and strengthening procedural and substantive rights to protect the individual from the state's arbitrary use of criminal mechanisms. ${ }^{1}$ However, human rights bodies have also worked to expand penality. ${ }^{2}$ In recent years, they have increasingly interpreted their mandate in monitoring compliance with human rights conventions as comprising the imposition of state obligations in criminal matters. ${ }^{3}$ In particular, the European Court of Human Rights (ECtHR) has developed ample case law demanding that states criminalise, prosecute and punish serious human rights violations, and avoid acts of 'criminal clemency' (decriminalisation and

PhD Candidate in Law, London School of Economics and Political Science (LSE). I am very grateful for the comments and discussion with Conor Gearty, Peter Ramsay, Diletta Machesi, Natasa Mavronicola, Laurens Lavrysen, Corina Heri, Barrie Sanders and Virginia Mantouvalou. I also benefited from thoughtful discussion and criticism at the ICON-S Annual Conference in Santiago (July 2019).

1 Substantive rights include, for instance, the provisions that crimes and punishment must be established by law, the prohibition of inhuman and degrading treatment or punishment and the prohibition upon unlawful or arbitrary detention. Procedural rights include the right to a fair trial, the presumption of innocence and the need to prove the guilt of the accused beyond reasonable doubt.

2 In this article, I use 'penality' to refer to the entire penal sphere, including its laws, sanctions, institutions, practices, discourses and representations. See, eg, D Garland, Punishment and Welfare: A History of Penal Strategies (Gower 1985) x; D Garland, 'Penality and the Penal State' (2013) 51 Criminology 475, 476.

3 See generally M Pinto, 'Awakening the Leviathan through Human Rights Law - How Human Rights Bodies Trigger the Application of Criminal Law' (2018) 34 Utrecht Journal of International and European Law 161; A Seibert-Fohr, Prosecuting Serious Human Rights Violations (Oxford University Press 2009). 
amnesty laws). ${ }^{4}$ The result is the emergence of a jurisprudence of 'coercive human rights law', whereby rights and freedoms at once humanise and enhance state penal practices. ${ }^{5}$

Some attention has been devoted in the literature to the evolution toward coercive human rights in human rights bodies' case law, and its immediate effects for the theory of both human rights and criminal law. ${ }^{6}$ Yet, there is little to no analysis on how this jurisprudence affects domestic criminal justice systems. Aiming to fill this gap, this article assesses some actual and potential implications that the ECtHR's duties to deploy the criminal law (might) have on domestic legal systems. It shows that the Court tends to present criminal accountability as indispensable to protect human rights. This approach may foster a 'culture of conviction' at the domestic level whereby punishment is seen as the end to pursue whatever the cost. ${ }^{7}$ While the ECtHR's jurisprudence currently refers to the duty to punish as an obligation of means, increased concern with the efficiency of criminal justice systems in preventing crime is leading the Court to consider whether adequate punishment has been imposed. Such an invocation of penal measures may have adverse implications in practice at the domestic level. Through the case study of the Modern Slavery Act (MSA), adopted in England and Wales in 2015, this article illustrates how domestic authorities may appropriate the language of coercive human rights to foster and legitimise penal expansion. The MSA appears to be heading toward a more repressive criminal justice system, with See, eg, K Kamber, Prosecuting Human Rights Offences: Rethinking the Sword Function of Human Rights Law (Brill 2017).

$5 \quad$ F Tulkens, 'The Paradoxical Relationship between Criminal Law and Human Rights' (2011) 9 Journal of International Criminal Justice 577, 538.

6 See, eg, Pinto (n 3); Tulkens (n 5); F Tulkens, 'Human Rights as the Good and the Bad Conscience of Criminal Law' in S Snacken and E Dumortier (eds), Resisting Punitiveness in Europe (Routledge 2012); M Sorochinsky, 'Prosecuting Torturers, Protecting Child Molesters Toward a Power Balance Model of Criminal Process for International Human Rights Law' (2009) 31 Michigan Journal of International Law 157; Seibert-Fohr (n 3); L Lazarus, 'Positive Obligations and Criminal Justice: Duties to Protect or Coerce?' in L Zedner and JV Roberts (eds), Principles and Values in Criminal Lan and Criminal Justice (Oxford University Press 2012); Kamber (n 4).

7 The idea that coercive human rights may encourage a 'culture of conviction' was firstly exposed, in the context of the Inter-American Court of Human Rights, by F Mégret and JP Calderón, 'The Move Towards a Victim-Centred Concept of Criminal Law and The "Criminalization" of Inter-American Human Rights Law: A Case of Human Rights Law Devouring Itself' in YHaeck, O Ruiz-Chiriboga and C Burbano-Herrera (eds), The Inter-American Court of Human Rights Theory and Practice, Present and Future (Intersentia 2015) 438. 
growing limitations on due process rights (for both defendants and victims of crime), harsher punishments and wider powers of arrest and detention. Conversely, criminal justice reform initiatives, directed at reducing unnecessary criminalisation and implementing alternatives to prison, are totally neglected.

This chapter is divided as follows. The first section presents current trends of penal expansion in Europe. Drawing on a number of influential texts on the 'carceral turn' in contemporary society, ${ }^{8}$ it connects the growing punitive tendencies in European states with the widespread assumption that criminal law can help address pressing social problems. The second section outlines the ECtHR's case law on coercive human rights and considers how the Court has laid the groundwork for promoting a 'culture of conviction' at the domestic level. The last section uses the MSA as a case study to investigate how domestic criminal justice systems may react to coercive human rights. Ultimately, it is argued that the ECtHR's jurisprudence has encouraged an expansion of penality in the UK under a benevolent guise that masks the oppressive effects of extensive powers to criminalise and punish.

\section{Rise of the penal state in Europe}

Several studies have observed a rise of punitiveness in the western world since the 1980s. ${ }^{9}$ This phenomenon, characterised by a decline of rehabilitative ideals, growth in incarceration rates, expanded application of criminal sanctions and increased police control, concerns not only the United States, but

8 On the 'carceral turn' in US and Western European societies, see generally E Bernstein, 'Carceral Politics as Gender Justice? The "Traffic in Women” and Neoliberal Circuits of Crime, Sex, and Rights' (2012) 41 Theory and Society 233, 236.

9 See, eg, D Garland, The Culture of Control: Crime and Social Order in Contemporary Society (Clarendon 2001); J Pratt, The New Punitiveness: Trends, Theories, Perspectives (Willan Pub 2005); J Simon, Governing Through Crime: How the War on Crime Transformed American Democracy and Created a Culture of Fear (Oxford University Press 2007); L Wacquant, Punishing the Poor: The Neoliberal Government of Social Insecurity (English language ed, Duke University Press 2009). 
also, to a lesser extent, certain European countries. ${ }^{10}$ The ever-expanding punitive outlook of contemporary democracies has raised great concern among progressive activists and scholars, who have long believed that reliance on criminal law and punishment should be as limited as possible. The history of criminal law is indeed largely a history of abuses and cruel practices. ${ }^{11}$ Criminalisation and punishment constitute the most severe forms of state interference with the individual's private sphere, and penal power, when increased, is prone to abuse and injustice. ${ }^{12}$

In the influential book The Culture of Control, David Garland critically examined these trends, by presenting a historical-cultural account of strategies of crime control since the 1970s in the United States and in the UK. ${ }^{13}$ He illustrated how a new 'culture of control' has risen and expanded in these two countries. This 'culture of control' is characterised by two patterns of action: a strategy of prevention and partnership between state and non-state agencies, and a strategy of 'punitive segregation' aimed at harsher punishment and more incapacitation. ${ }^{14}$ Garland singled out several examples of this phenomenon, including mandatory sentencing laws, more proactive and preventive policing efforts, harsher penalties, emphasis on 'the victim' as justification for more severe responses to crime, increased concern with prevention, harm-reduction and risk management, community notification laws and offenders' registers, private policing, zero tolerance policies and Anti-Social Behaviour Orders. ${ }^{15}$ Garland

10 S Snacken, 'Resisting Punitiveness in Europe?’ (2010) 14 Theoretical Criminology 273.

11 N Jareborg, 'What Kind of Criminal Law Do We Want' in Annika Snare (ed), Beware of Punishment: On the Utility and Futility of Criminal Law, vol 14 (Pax Forlag 1995) 18.

12 PH Van Kempen (ed), Criminal Law and Human Rights (Ashgate 2014) xi.

13 Garland, The Culture of Control (n 9).

14 ibid 139-146.

15 ibid ch 6-7. 
also suggested that, despite considerable variation from place to place and some exceptions, other western industrialised nations appeared to be heading down the same path. ${ }^{16}$

This is also the position of Loïc Wacquant. For the French sociologist, 'the explosive growth of the scope and intensity of punishment' also affected Western Europe. ${ }^{17}$ In Punishing the Poor, Wacquant reconnected this phenomenon to the global expansion of neo-liberalism, which has been imported into the European continent from the United States and has transformed the welfare state into a penal one. ${ }^{18}$ According to Wacquant, the 'European road' to punitiveness (with French, Dutch, Italian and other variants) is characterised by social and penal policies that seek to regulate those on the margins of society. ${ }^{19}$ Welfare services and punitive interventions are combined for the purpose of supervising, controlling, criminalising and punishing 'the poor'. The French sociologist observed that in Europe the 'penalization of poverty' is mainly driven by the police and the courts rather than the prison. ${ }^{20}$ Elements of the European punitive tendency are the upsurge of police intervention, the escalation of penalties for repeated offences, the subordination of social services to judicial authorities, and the extension of powers to arrest and detain. ${ }^{21}$

The punitive trends described by Garland and Wacquant sped up in the wake of the attacks of 11 September $2001 .^{22}$ On both sides of the Atlantic, several countries adopted numerous counter-terrorism

16 ibid 91.

17 Wacquant (n 9) xvi.

18 ibid 20-21.

$19 \quad$ ibid 24.

$20 \quad$ ibid.

21 ibid pt 4 .

22 E Dumortier et al, 'The Rise of the Penal State: What Can Human Rights Do About It?' in Sonja Snacken and Els Dumortier (eds), Resisting Punitiveness in Europe (Routledge 2012) 109-110. 
measures that bolstered their penal systems. Western democracies passed laws aimed at facilitating arrests and detentions and at reducing defendants' rights whilst increasing governmental powers to interfere with individuals' privacy and private life. ${ }^{23}$ However, the rise of the penal state has involved not only tangible developments within the criminal justice system, but also more punitive attitudes at the level of social and political discourse. This phenomenon involves a growing sensibility about revenge by crime victims, ${ }^{24}$ renewed attention toward 'popular' demands of punishment, ${ }^{25}$ diffusion of images of insecurity by the media, ${ }^{26}$ and political initiatives promoting 'law and order' thinking. ${ }^{27}$ The normal citizen is transformed into a victim of crime, whose vulnerability requires a greater resort to criminalisation and penal severity. ${ }^{28}$ The underlying assumption is that criminal sanction is an effective tool for reducing crime, providing justice and solving complex social issues. It is a form of 'penal optimism', ${ }^{29}$ summed up by the assertion that 'prison works.' ${ }^{30}$ This punitive fervour attracts not only 'law and order' politicians but at times also

23 See generally G Agamben, State of Exception (University of Chicago Press 2005) 3; B Evans, Liberal Terror (Polity Press 2013).

I Aertsen, 'Punitivity from a Victim's Perspective' in S Snacken and E Dumortier (eds), Resisting Punitiveness in Europe (Routledge 2012).

See generally J Pratt, Penal Populism (Routledge 2007); A Bottoms, 'The Philosophy and Politics of Punishment and Sentencing' in CMV Clarkson and R Morgan (eds), The politics of sentencing reform (Clarendon Press 1995).

Simon (n 9) 135.

R Reiner, Law and Order: An Honest Citizen's Guide to Crime and Control (Polity Press 2007).

P Ramsay, The Insecurity State: Vulnerable Autonomy and the Right to Security in the Criminal Law (Oxford University Press 2012) 228; Simon (n 9) 76.

CM Webster and AN Doob, 'Penal Optimism: Understanding American Mass Imprisonment from a Canadian Perspective' in KR Reitz (ed), American Exceptionalism in Crime and Punishment (Oxford University Press 2017).

The phrase was coined by former British Home Secretary Michael Howard in a speech at the British Conservative Party conference on 6 October 1993 ('Let us be clear. Prison works. It ensures that we are protected from murderers, muggers and rapists, and it makes many who are tempted to commit crime think twice.'). See C Brown, 'Howard Seeks to Placate "Angry Majority": Home Secretary Tells Party' The Independent (7 October 1993) <http:/ /www.independent.co.uk/news/uk/howard-seeks-to-placate-angry-majority-home-secretary-tells-party-thatbalance-in-criminal-justice-1509088.html> accessed 16 December 2019. 
liberal and progressive movements (victim advocates, feminist activists and ecological groups), which view the penal system as a tool of social reform and a protection for vulnerable individuals. ${ }^{31}$

The rise of the penal state has not involved every European country in the same way. As Sonja Snacken reports, some states 'do not easily fit this bleak vision of punitiveness'. ${ }^{32}$ While in certain countries imprisonment rates have grown steadily (the UK, Spain, the Netherlands, France), in others the prison population has remained stable (Scandinavian countries, Germany) or has even decreased (Eastern European countries). ${ }^{33}$ In this regard, it has been observed that levels of punitiveness are to be correlated with welfare investment and political economy, ${ }^{34}$ but also with different democratic political structures. ${ }^{35}$ Moreover, for some authors, if Europe has never achieved the same level of punitiveness as the United States, this is due to the different role that human rights law has played in the two contexts. ${ }^{36}$ The European Convention on Human Rights (ECHR) is often mentioned as one of the barriers against an uncontrolled expansion of penality. ${ }^{37}$ According to Denis Salas, for instance, the monitoring role of the

AJ Do Amaral, ‘The Penal Policy of Human Rights' (2013) 1 Zeitschrift für Internationale Strafrechtsdogmatik 61, 61; quoting ML Karam, Recuperar o Desejo Da Liberdade e Conter o Poder Punitivo, vol 1 (1st edn, Lumen Juris 2009) 4; H Aviram, 'Progressive Punitivism: Notes on the Use of Punitive Social Control to Advance Social Justice Ends' (2019) UC Hastings Research Paper No 364 <www.ssrn.com/abstract=3404276> accessed 16 December 2019.

ibid.

N Lacey, The Prisoners' Dilemma: Political Economy and Punishment in Contemporary Democracies (Cambridge University Press 2008).

T Lappi-Seppälä, 'Explaining National Differences in the Use of Imprisonment' in S Snacken and E Dumortier (eds), Resisting Punitiveness in Europe (Routledge 2012).

Dumortier et al (n 22) 113. 
ECtHR is a key factor in explaining the more humane and moderate penal and sentencing polices in the European continent. ${ }^{38}$

It is probably true that ECtHR case law has somewhat constrained the penal actions of European states. Examples that are often reported are the abolition of the death penalty, the protection of prisoners' rights, the prohibition of indefinite detention, the decriminalisation of homosexuality and the protection of freedom of expression against undue criminalisation. ${ }^{39}$ Nonetheless, the jurisprudence of the ECtHR is also ambivalent. Not only has the Court at times hesitated to counter expansive national penal policies, but in some other cases it has backed or even promoted the introduction of new criminal offences, more policing powers, the institution of criminal proceedings and harsher punishments.

\section{ECtHR case law on coercive human rights}

\section{A. State obligations in criminal matters}

The ECtHR has developed a robust body of case law requiring states to deploy their domestic criminal law to counter human rights violations and protect the rights and freedoms enshrined in the ECHR..$^{40}$ As Laurens Lavrysen has shown in his chapter, ${ }^{41}$ the duty to have recourse to criminal law solutions generally has two strands. First, the Court demands that states criminalise conduct that harms individuals' liberties.

D Salas, La Volonté de Punir: Essai Sur Le Populisme Pénal (Hachette Littératures 2008) 124-140; mentioned in Dumortier et al (n 22) 113.

Dumortier et al (n 22) 114-120. On freedom of expression, see also Stephanos Stavros' chapter in this volume.

40 Kamber (n 4); S Manacorda, “'Dovere Di Punire”? Gli Obblighi Di Tutela Penale Nell'era Della Internazionalizzazione Del Diritto' in M Meccarelli, P Palchetti and C Sotis (eds), Il lato oscuro dei diritti umani: Esigenze emancipatorie e logiche di dominio nella tutela giuridica dell'individuo (Universidad Carlos III De Madrid 2014); Lazarus (n 6). 
Second, it requires that effective criminal law mechanisms (investigation, prosecution and punishment) are put in place and pursued effectively as enforcement tools of human rights provisions.

The ECtHR has provided for the duty to criminalise in relation to Articles 2, 3, 4 and 8 ECHR. ${ }^{42}$ Given the scope of this chapter, I shall focus here only on Article 4. In Siliadin v France, for instance, the Court censured French law for not providing sufficient and effective criminal law protection against 'servitude'. ${ }^{43}$ The case involved a Togolese girl who had worked for four years as a domestic servant for a married couple without remuneration or freedom of movement. The ECtHR found that Article 4 ECHR 'must be seen as requiring the penalisation and effective prosecution' of 'any act aimed at maintaining a person' in a situation of slavery, servitude, forced or compulsory labour. ${ }^{44}$ Similarly, in $C N$ $v$ United Kingdom, the Court found that the Government's failure to properly investigate the complaints of domestic servitude made by the applicant, a woman who had travelled to the UK from Uganda, was due to the absence of specific legislation criminalising such a wrongdoing. ${ }^{45}$ In Rantsev v Cyprus and Russia, the victim, a Russian woman, had been trafficked from Russia to Cyprus for reasons of sexual exploitation and the European judges extended the protection offered by Article 4 to trafficking in human beings. ${ }^{46}$ As a result, states are required to adopt measures intended to prevent trafficking, protect victims, and criminalise and punish traffickers. ${ }^{47}$

$42 X$ and $Y v$ Netherlands Series A no 91 (1986) 8 EHRR 235, para 27; MC v Bulgaria (2005) 40 EHRR 20, paras 150 and 174; Kiliç v Turkey (2001) 33 EHRR 58, para 62; Cestaro v Italy App No 6884/11 (ECtHR, 7 May 2015) para 246; CN and V v France App No 67724/09 (ECtHR, 11 October 2012) para 105.

Siliadin v France (2006) 43 EHRR 16, para 89.

44 ibid para 112.

45 CN v United Kingdom (2013) 56 EHRR 24, para 81.

46 Rantsev v Cyprus and Russia (2010) 51 EHRR 1, para 282. See also Chowdury and Others v Greece App No 21884/14 (ECtHR, 30 March 2017) para 86. 
The ECtHR also orders states to enforce their criminal law. ${ }^{48}$ The Court has recently clarified that, in cases of serious violence such as assaults for racial reasons or police ill-treatment, civil compensation or administrative proceedings are not enough and prosecution is required. ${ }^{49}$ The European judges have tried to attenuate this provision by clarifying that ' $[t]$ he obligation to conduct an effective investigation is an obligation not of result but of means'. ${ }^{50}$ However, this qualification is rendered immaterial when the judges hold that the institution of criminal proceedings cannot be detached from their 'issue naturelle, namely the punishment of those responsible. ${ }^{51}$ In the Court's opinion, 'not doing enough to prosecute and punish those responsible' and confining the state's reaction to the mere payment of compensation makes any investigation ineffective in practice. ${ }^{52}$ In Ali and Ayse Duran v Turkey, the European judges explained that ' $[\mathrm{w}]$ hile there is no absolute obligation for all prosecutions to result in conviction or in a particular sentence, the national courts should not under any circumstances be prepared to allow lifeendangering offences and grave attacks on physical and moral integrity to go unpunished'. ${ }^{53}$ Finally, the ECtHR insists that those responsible for serious human rights violations should serve a severe sentence. ${ }^{54}$

48 Öneryildizv Turkey (2005) 41 EHRR 20, para 94; Ali And Ayse Duran v Turkey App No 42942/02 (ECtHR, 8 May 2008) para 61.

49 Movsesyan v Armenia App No 27524/09 (ECtHR, 16 November 2017) para 74; Jeronovičs v Latvia App No $44898 / 10$ (ECtHR [GC] 05 July 2016) para 105; OR and LR v Moldova App No 24129/11 (ECtHR, 30 October 2018) para 77. 77. in a case of police ill-treatment). 
In the Court's view, the duty to resort to criminal law would lose much of its meaning if perpetrators were punished with too lenient a sanction. ${ }^{55}$

Where the ECtHR is confronted with situations of human rights abuses of a certain gravity (eg, torture, killings, trafficking and forced labour, as well as domestic and sexual violence), criminal justice appears as an indispensable element of human rights protection and promotion. The underlying rationales are mostly deterrence, prevention, and adherence to, or restoration of, the rule of law. ${ }^{56}$ For the Court, criminal law safeguards society as a whole by ending impunity and providing general human rights protection. ${ }^{57}$ The ECtHR also has a tendency to require criminal accountability in the interests of individual victims. In Jelić v Croatia, for instance, the European judges noted that 'among the main purposes of imposing criminal sanctions [is] retribution as a form of justice for victims' ${ }^{58}$ Even if the Court has yet to recognise the victim's right to have criminal proceedings instituted against third parties,${ }^{59}$ criminal law mechanisms are to be available to those affected by serious human rights violations. ${ }^{60}$ As Krešimir Kamber has persuasively contended, the victim has a 'right-claim to the application of criminal law mechanisms' without any flaws or culpable failures in the process. ${ }^{61}$ This tendency is clearly visible in $A l$ Nashiri v Romania and Abu Zubaydah v Lithuania, where the ECtHR held that 'the notion of an "effective

55 Nikolova and Velichkova v Bulgaria (2009) 48 EHRR 40, para 62 (the ECtHR held that punishing police ill-treatment resulting in death with suspended terms of imprisonment amounted to a violation of Article 2 ECHR).

Opuzv Turkey (2010) 50 EHRR 28, para 128.

OR and LR $v$ Moldova (n 49) paras 58-59. 68 EHRR11, para 69.

$61 \quad$ Kamber (n 4) 507. 
remedy" for the victim entails criminal proceedings "leading to the identification and punishment of those responsible. ${ }^{62}$

\section{B. Encouraging a 'culture of conviction'}

Throughout its case law, the ECtHR has maintained that criminalisation, prosecution and punishment of certain abuses are required to secure human rights. In so doing, the Court shows a great confidence in the deployment of penal powers and gives criminal law a positive outlook, as a painkiller to redress social and moral harms. ${ }^{63}$ The gravity of the harm caused and the seriousness of the abuses committed also contribute to presenting criminal law as the obvious and self-evident instrument to respond to serious human rights violations. Critical arguments concerning the risks of over-criminalisation are, on the other hand, dismissed. ${ }^{64}$

The European judges appear to regard criminal law solutions as the principal and most effective ways to prevent grave ECHR breaches and give redress to victims. Currently, the ECtHR's jurisprudence refers to the duty to punish and prosecute as obligations of means. However, increased concern with the effectiveness of the criminal justice system in preventing crime and impunity is leading the Court to ultimately consider whether adequate punishment has been, or could have been, imposed. ${ }^{65}$ When criminal justice systems are criticised, it is usually because they are not effective enough in securing convictions and punishments. In Nasr and Ghali v Italy, for example, Italian investigators and judges had para 673.

63 Similarly, in the context of the IACtHR, DR Pastor, 'La Deriva Neopunitivista y El Desprestigio Actual de Los Derechos Humanos' [2006] Jura Gentium <http://www.juragentium.org/topics/latina/es/pastor.htm> accessed 16 December 2019. 
identified and convicted those responsible for the 'extraordinary rendition' of the Egyptian imam Abu Omar. ${ }^{66}$ The ECtHR also acknowledged that the investigations had been 'effective et profonde' ${ }^{67}$ However, Italy was found in violation of the Convention because it had created a situation of impunity by not punishing some of the convicted persons. ${ }^{68}$ Clearly, the Court's concern here is not with the adequacy of the process but rather with the efficiency of results. Only the imposition of an adequate (ie non-lenient) punishment on those deemed responsible is considered as an effective remedy. ${ }^{69}$ On the other hand, absence of criminal accountability is regarded as a human rights violation per se. ${ }^{70}$ The assumption that a general atmosphere of impunity contributes to the commission of further crimes has led Judge Ksenija Turković to assert that passivity in prosecuting 'may be equated with complicity'. ${ }^{71}$ For this reason, the Court appears to be willing to accommodate various limitations to the principle of fair trial, ${ }^{72}$ statutes of limitations and acts of criminal clemency when they are perceived to foster impunity. ${ }^{73}$

The insistence on coercive human rights also has the effect of pulling non-punitive remedies into the criminal justice orbit. While the Court at times demands states to combine criminal law with a wide range of other social and legislative measures, the latter tends nonetheless to be conceived within a criminal law

Nasr and Ghali (n 51).

67 ibid para 272.

68 ibid. Italy never sought the extradition of the CIA agents who had been convicted and the Italian President of the Republic pardoned three of them.

K Turković, 'International and National Courts Confronting Large-Scale Violations of Human Rights' (2016) <www.echr.coe.int/Documents/Speech_20160129_Turkovic_JY_ENG.pdf> accessed 16 December 2019 (speech at a seminar for the opening of the ECHR's judicial year in 2016). para 260; Marguš v Croatia (2016) 62 EHRR 17, para 139. 
paradigm. ${ }^{74}$ By the same token, victims' protection is mostly to be ensured by means of criminal proceedings and even restorative measures are incorporated into the existing punitive framework. As stated in Rantsev v Cyprus and Russia, states have positive obligations to put in place an appropriate legislative and administrative framework, to ensure the enjoyment of human rights, to take protective measures on behalf of victims, to investigate human rights breaches, and to cooperate with each other in cases of cross-border violations. ${ }^{75}$ Although the preventive and protective measures that, according to the ECtHR, should accompany criminal law mechanisms are not strictly 'penal' in nature, it is primarily for criminal justice institutions (police, prosecutors, criminal courts) to implement and enforce them. As a result, the focus shifts from protection and compensation to prosecution and punishment. In August v United Kingdom, for example, the applicant, a minor, complained that his rights under Article 8 ECHR had been violated because he had not been awarded compensation as a victim of prostitution. ${ }^{76}$ The Court rejected his claim, arguing that the conviction of his abuser was a sufficient response to the violation. ${ }^{77}$

Commenting on the assertion that the European Court has become a 'machine that encourages criminal inflation', ${ }^{78}$ former ECtHR judge Françoise Tulkens contends that 'while it is true [...] that the Court sometimes gives in to the questionable charm of more severe criminalization, the reality is more complex'. ${ }^{79}$ In fact, the Court has not ceased to set restrictions on the use of penal powers by European states. However, the latter function coexists with the other here presented, aimed at holding perpetrators

74 See, eg, Rantsev (n 46) para 284. See also Vladislava Stoyanova's chapter in this volume.

75 Rantsev (n 46) paras 286-289.

76 August v. United Kingdom (2003) 36 EHRR CD115.

77 ibid.

78 Y Cartuyvels, 'Droit Pénal et Droits de l'homme, Un Retournement?' in Michel van de Kerchove and others (eds), Les droits de l'Homme: épée ou bouclier du droit pénal? (Presses de l’Université Saint-Louis Series 2007) 43. 
of human rights violations criminally accountable. ${ }^{80}$ Coercive human rights are the result of a certain doublethink in the Court's jurisprudence. While the ECtHR still advances its moderating influence in some areas of criminal law, it has started bolstering and requiring penality in others. In so doing, the ECtHR sends an ambiguous message to domestic criminal justice systems, which are required to enforce coercive human rights obligations while guaranteeing due process rights or limiting their penal tendency in some other contexts. ${ }^{81}$ It is likely that this mixed message leads to undesirable outcomes. As presented in the first section, some European states are already expanding their criminal justice systems with troublesome results. Coercive human rights obligations may, in turn, foster a further 'culture of conviction' whereby punishment is considered as the end to pursue whatever the cost. ${ }^{82}$ As Liora Lazarus has noted, 'case law is one thing, it is another matter how states and governments translate the messages they are hearing from the ECtHR [...], and how they are incorporating these messages into the rhetoric of public protection'. ${ }^{83}$ The danger, far from being hypothetical, is that domestic authorities interpret the decisions of the Court as enabling them to increase the level of punitiveness. Put differently, domestic authorities may take advantage of the jurisprudence on coercive human rights to enhance penal measures to the detriment of individuals' freedoms. ${ }^{84}$ This expansion, at the same time, is easily welcomed into the system because it is justified by the language and rhetoric of rights. ${ }^{85}$ Growing policing powers, the introduction of new criminal offences and wide-ranging incarceration become acceptable and even Anti-Impunity and the Human Rights Agenda (Cambridge University Press 2016) 37; Mégret and Calderón (n 7 ) 438. 19. 
desirable if presented as necessary for rights' protection. In other words, the Court's human rights case law is used as a leverage for justifying the expansion of the penal state.

\section{The Modern Slavery Act 2015}

In this section, the MSA is taken as a case study to illustrate how the jurisprudence of the ECtHR on coercive human rights is translated at the domestic level. The Act and its application are analysed to show that domestic authorities may appropriate the language of human rights to foster and legitimise penal expansion. Contrary to the opinions of certain authors, ${ }^{86}$ it is contended that a rights-based approach to complex social problems (eg human trafficking and labour exploitation) - especially when influenced by the ECtHR case law - is not in opposition, but rather conducive, to the deployment of more far-reaching criminal law.

The MSA is an anti-trafficking legislation passed in England and Wales in 2015. It aims to address what is commonly called 'modern slavery', namely a wide range of exploitative practices, including slavery, forced labour and trafficking in human beings. It does so by strongly relying on criminal law measures, such as heavy penalties and provisions to facilitate investigation, prosecution and conviction. The underlying justification for the Act is that 'modern slavery' is a serious human rights violation that requires prompt criminal accountability. The increasingly intertwined relationship between 'human rights problems' and 'criminal law solutions' has been underscored by Theresa May in an article she wrote in The Telegraph one year after the enactment of the MSA:

86 C Leigh, 'Anti-Trafficking Campaigns, Sex Workers and the Roots of Damage' in P Kotiswaran and S Okyere (eds), State and the Law: Beyond Trafficking and Slavery Short Course, vol 3 (Beyond Trafficking and Slavery 2015); Danielle Worden, 'Sex Trafficking: Towards a Human Rights Paradigm' (2018) 22 International Journal of Human Rights 709. 
These crimes must be stopped ... This is the great human rights issue of our time, and as Prime Minister I am determined that we will make it a national and international mission to rid our world of this barbaric evil. ${ }^{87}$

The case law of the ECtHR had a prominent influence on the adoption of the MSA.$^{88}$ In 2012 , the Court rendered the judgment of $C N v$ United Kingdom, involving an Ugandan national who had been forced into working as a live-in carer with no significant payment and confiscated identity and travel documents. ${ }^{89}$ Recalling a previous decision in Siliadin v France and Rantsev v Cyprus and Russia, ${ }^{90}$ the ECtHR held that the UK legislative framework in place at the relevant time had been inadequate to afford practical and effective protection against violations of Article 4 ECHR. ${ }^{91}$ The Court also censured as ineffective the investigation by the British authorities into the applicant's complaint of domestic servitude. ${ }^{92}$ The UK had already introduced the various offences of 'slavery, servitude, and forced or compulsory labour' in section 71 of the UK Coroners and Justice Act 2009. However, the ECtHR case law on Article 4 ECHR, together with difficulties in enforcement and lack of clarity of section 71 , fuelled interest in enacting a

T May, 'My Government will lead the way in Defeating Modern Slavery' (The Telegraph, 31 July 2016) <www.telegraph.co.uk/news/2016/07/30/we-will-lead-the-way-in-defeating-modern-slavery/> accessed 16 December 2019.

88 Home Office, 'Modern Slavery Bill: European Convention On Human Rights: United Nations Convention On The Rights Of The Child: Memorandum By The Home Office' (2014) paras 3, 8 and 40 <https://assets.publishing.service.gov.uk/government/uploads/system/uploads/attachment_data/file/318618/EC HRmemoModernSlavery.pdf> accessed 16 December 2019; see also V Mantouvalou, 'The UK Modern Slavery Act 2015 Three Years On: The UK Modern Slavery Act 2015 Three Years On’ (2018) 81 Modern Law Review 1017, 1020; I Turner, 'Positive Obligations and Article 4 of the European Convention on Human Rights: A Defence of the UK's Human Rights Act 1998' (2014) 18 International Journal of Human Rights 94, 105; J Haynes, 'The Modern Slavery Act (2015): A Legislative Commentary' (2016) 37 Statute Law Review 33, 37.

$C N($ n 45).

Siliadin (n 43); Rantsev (n 46).

$C N(\mathrm{n} 45)$ para 76.

ibid paras 79-81. 
more comprehensive act, ${ }^{93}$ which would 'equip the United Kingdom to fight modern slavery' ${ }^{94}$ The MSA consolidated and simplified existing offences and increased sentences. The maximum penalty for slavery, servitude, forced or compulsory labour and human trafficking is now life imprisonment. ${ }^{95}$ Additionally, the Act provides for a confiscation regime for individuals convicted of 'modern slavery' offences; ${ }^{96}$ introduces Slavery and Trafficking Prevention and Risk Orders to restrict the activity of those who pose a risk of causing harm; ${ }^{97}$ and establishes an Independent Anti-Slavery Commissioner. ${ }^{98}$ Finally, the Act lays down various provisions for the protection of victims, including a new defence for victims who commit an offence, ${ }^{99}$ as well as a section on transparency in supply chains. ${ }^{100}$

The stated purpose of the MSA is to strengthen criminalisation initiatives, facilitate the work of law enforcement officers and increase prosecution rates. ${ }^{101}$ The approach adopted builds upon the British government's strategy to counter organised crime and terrorism. ${ }^{102}$ The regulation of trafficking and exploitation heavily relies on law enforcement and crime control, while the causes of trafficking and the

93 Home Office, 'Modern Slavery Bill: European Convention On Human Rights: United Nations Convention On The Rights Of The Child: Memorandum By The Home Office' (n 88) para 8; Haynes (n 88) 5; C Barclay and S Foster, 'The Modern Slavery Act 2015: Good Intentions and Sending out the Right Message' (2017) 22 Coventry Law Journal 1, 2 .

See Centre For Social Justice, 'It Happens Here: Equipping the United Kingdom to Fight Modern Slavery' (2013) $<$ https://www.centreforsocialjustice.org.uk/library/happens-equipping-united-kingdom-fight-modern-slavery > accessed 16 December 2019.

95 MSA, s 5(1)(a).

96 ibid s 7.

$97 \quad$ ibid part 2.

$98 \quad$ ibid s 41.

99 ibid s 45.

100 ibid s 54.

101 Mantouvalou (n 88) 1021.

102 J Fudge, 'The Dangerous Appeal of the Modern Slavery Paradigm' in P Kotiswaran and S Okyere (eds), State and the Law: Beyond Trafficking and Slavery Short Course, vol 3 (Beyond Trafficking and Slavery 2015) 21. 
structural factors that create vulnerability remain unaddressed. ${ }^{103}$ Arguably, these exploitative factors are even promoted by the government, through immigration policies of exclusion, such as preventing asylum seekers from working and tying overseas domestic workers to their employers. ${ }^{104}$ The assumption is that 'modern slavery' can be 'solved' by targeting individual players rather than the social processes that normalise exploitation. ${ }^{105}$ This assumption, among other reasons, ${ }^{106}$ finds justification in the ECtHR case law, which has transformed criminal law into the primary instrument of human rights protection. Criminal law is also used as a communication tool to send a clear message to abusers that their conduct is not tolerated. In Theresa May's words:

This landmark legislation sends the strongest possible signal to criminals that if you are involved in this vile trade you will be arrested, you will be prosecuted and you will be locked up. ${ }^{107}$

The focus on crime reduction, deterrence and punishment is in line with, and implements, the UK's international obligations under the UN Trafficking Protocol, the Council of Europe Convention on Action against Trafficking in Human Beings and the EU Anti-Trafficking Directive. ${ }^{108}$ But it is also

103 J Collins, 'Exploitation of Persons and the Limits of the Criminal Law' [2017] Criminal Law Review 169.

104 K Roberts, 'The Modern Slavery Bill: Migrant Domestic Workers Fall through the Gaps' in P Kotiswaran and S Okyere (eds), State and the Law: Beyond Trafficking and Slavery Short Course, vol 3 (Beyond Trafficking and Slavery 2015) 14-19.

105 Fudge (n 102) 21-23.

106 A focus on individual criminal responsibility may also be explained by the increasing tendency of contemporary democracies of using criminal law as a relatively easy and symbolic tool to address social problems, thereby avoiding more reasoned and comprehensive legal and political actions. See section II above.

107 Home Office, 'Historic Law to End Modern Slavery Passed' (GOV.UK) <www.gov.uk/government/news/historiclaw-to-end-modern-slavery-passed> accessed 16 December 2019.

108 These instruments mainly promote a criminal law approach to human trafficking. See, eg, JC Hathaway, 'The Human Rights Quagmire of "Human Trafficking”" (2008) 49 Virginia Journal of International Law 1, 26; M Eriksson, 'The Prevention of Human Trafficking - Regulating Domestic Criminal Legislation through the European Convention on Human Rights' (2013) 82 Nordic Journal of International Law 339. 
compatible with, if not required by, the UK's obligations under the ECHR. ${ }^{109}$ The jurisprudence of the ECtHR supports rather than challenges the use of a criminal justice framework to address 'modern slavery'. Section 1(2) of the MSA is indicative in this respect, when it clarifies that the offence of slavery, servitude, forced and compulsory labour has to be construed in accordance with Article 4 ECHR. ${ }^{110}$

Three examples illustrate the limitations of an act that uses adherence to international obligations as ways to justify extensive penality.

\section{A. Sentencing}

First, in terms of penalties the MSA fully endorses the 'prison works' rhetoric. Theresa May's words are again illustrative:

Offences committed in connection with modern slavery are some of the most serious that can be committed, so the Bill extends the maximum available sentence to life imprisonment. That will ensure that the worst perpetrators can receive the lengthy custodial sentences that they deserve. Tough sentences will also act as a powerful deterrent to others. ${ }^{111}$

Although life in prison is yet to be used, existing case law has shown a tendency to impose higher custodial sentences. ${ }^{112}$ In $R v$ Zielienski (David), the offender had conspired with his family to deceive a group of

109 A Weatherburn, 'Using an Integrated Human Rights-Based Approach to Address Modern Slavery: The UK Experience’ (2016) 2 European Human Rights Law Review 184, 188.

110 MSA, s 1(2).

111 Hansard HC col 172 (8 July 2014).

112 Mantouvalou (n 88) 1026. 
Polish nationals to travel to the UK, on the promise of a well-paid job. ${ }^{113}$ They were instead housed in appalling conditions and their wages were confiscated. The Court of Appeal increased a sentence of four years for trafficking offences to seven years, confirming that 'modern slavery' offences are to be treated with severity. ${ }^{114}$ First, Lord Justice Davis explained that sentences in cases of 'modern slavery' must make clear that 'every vulnerable victim of exploitation will be protected by the criminal law'. ${ }^{115}$ Endorsing the judge of first instance, Lord Justice Davis accepted that there was a 'clear, obvious and continuing need to punish' traffickers and 'deter others who would seek to profit from the oppression of others'. ${ }^{116}$ Then, on this basis, he had no doubt that Zielienski's sentence was 'unduly lenient' and had to be 'significantly increased'. ${ }^{117}$

The trend toward higher penalties is even more visible in $\mathrm{R} v$ Iyamu (Josephine). ${ }^{118}$ Iyamu had been convicted for having arranged the travel of five individuals to Europe with a view to exploitation. With one exception, all victims had been made aware that they were to work as prostitutes once in Germany and Italy. They had been subject to juju rituals, trafficked to Europe and forced to sell their bodies to repay their 'debts'. Iyamu was initially sentenced to 14 years' imprisonment. However, the Court of Appeal found the latter penalty 'unduly lenient' and increased it to 18 years' imprisonment. ${ }^{119}$ Without wishing to assess whether the latter penalty is appropriate, it is important to focus here on the language used by

$113 \mathrm{R} v$ Zielinski (David) [2017] EWCA Crim 758.

114 ibid at para 28.

115 ibid, quoting Attorney General's Reference Nos 2, 3, 4 and 5 of 2013 (R $v$ William Connors and Others) [2013] EWCA Crim 324 at para 10.

116 Zielinski (n 113) at para 21, quoting the decision of the Crown Court at Bedford who sentenced Zielinski in the first instance.

117 ibid 758 at para 27.

118 R. v Iyamu (Josephine) [2018] EWCA Crim 2166.

119 ibid at paras 50-52. 
the Court and its emphasis on the need for a 'severe sentence'. ${ }^{120}$ The Court of Appeal described Iyamu's lack of remorse and continued denial of responsibility for what occurred ${ }^{121}$ and concluded:

Overall, therefore, the facts and circumstances of this case compel the conclusion that this sentence, in our judgment, ought to be increased. Offending of this gravity requires condign sentencing. It also requires that persons be deterred from engaging in offending of this kind ... Those who are within the reach of the jurisdiction of the courts of England and Wales should expect severe sentencing in this context. Those who engage in vicious, ruthless and heartless human trafficking of this particular kind are playing for high stakes. They need to know that the courts will show no mercy when their criminality is exposed. ${ }^{122}$

\section{B. Prosecution of victims}

Second, a framework heavily focused on crime encourages a rigid dichotomy between victims and perpetrators. However, it is not uncommon for people who have been exploited to commit offences or become involved in trafficking themselves. ${ }^{123}$ A criminal record for victims of 'modern slavery' is highly detrimental because it would limit their access to lawful employment, have an impact on their immigration status and render contact with state authorities less likely in the future. ${ }^{124}$ In other words, it makes victims more vulnerable to further exploitation. A series of international and European instruments have

$120 \quad$ ibid at para 51.

121 ibid at para 46.

122 ibid at para 51 (emphasis added).

123 S Rodríguez-López, ‘(De)Constructing Stereotypes: Media Representations, Social Perceptions, and Legal Responses to Human Trafficking' (2018) 4 Journal of Human Trafficking 61, 68.

$124 \mathrm{R} v \mathrm{EK}$ [2018] EWCA Crim 2961 at para 2. 
acknowledged this problem and have encouraged the adoption of non-punishment clauses for victims of trafficking and labour exploitation. ${ }^{125}$ In place of a non-punishment clause, section 45 of the MSA provides for a statutory defence for individuals compelled to commit certain criminal offences as a result of their exploitation. ${ }^{126}$ The defence does not apply to various crimes, such as sexual offences, offences involving serious violence, or robbery and burglary. ${ }^{127}$

Despite good intentions, section 45 is problematic. ${ }^{128}$ First, it is designed not primarily to protect victims of 'modern slavery', but to transform them into reliable witnesses who can facilitate the work of law enforcement officers. ${ }^{129}$ Its stated purpose is to encourage victims to come forward and give evidence without fear of being convicted. ${ }^{130}$ Second, a criminal law approach to trafficking criminalises victims who are compelled to commit offences more often than not, even when a defence is provided. Trafficked victims often do not self-identify as having been trafficked and may distrust the authorities and even their

125 See, eg, Council of Europe Convention on Action Against Trafficking in Human Being, adopted on 1 February 2008 , CETS No 197, art 26; Directive 2011/36/EU, 5 April 2011, art 8. According to Piotrowicz and Sorrentino, the obligation to protect victims of trafficking in Rantsev [(n 46) para 284] requires the enactment of non-punishment clauses (RW Piotrowicz and L Sorrentino, 'Human Trafficking and the Emergence of the Non-Punishment Principle' (2016) 16 Human Rights Law Review 669, 681).

126 MSA, s 45.

127 ibid s 45(7).

128 For a critique on how the defence is formulated see SSM Edwards, 'Coercion and Compulsion - Re-Imagining Crimes and Defences' [2016] 12 Criminal Law Review 876; K Laird, 'Evaluating the Relationship between Section 45 of the Modern Slavery Act 2015 and the Defence of Duress: An Opportunity Missed?’ [2016] Criminal Law Review 395.

129 On victims of human trafficking as witnesses, see T Ward and S Fouladvand, 'Human Trafficking, Victims' Rights and Fair Trials' (2018) 82 Journal of Criminal Law 138.

130 Home Office, 'Modern Slavery Act 2015 Review: Fourth Interim Report' (2019) s 4.1 .2 <https://www.gov.uk/government/publications/modern-slavery-act-review-2015-fourth-interim-report> accessed 16 December 2019. 
lawyer. ${ }^{131}$ As a result, in the UK victims continue to be prosecuted for offences they were forced to commit. $^{132}$

The following examples may help illustrate the problem here. The first case is $R v$ Joseph (Verna Sermanfure). ${ }^{133}$ The human rights NGO Anti-Slavery International, acting as intervener, invited the Court of Appeal to reconsider the approach UK courts had taken prior to the enactment of the MSA in respect of prosecution of trafficked victims who offended. In five out of six of the conjoined appeals, the interested parties had been granted the status of victims of trafficking after their conviction. Only in two cases the Court of Appeal allowed the appeals and quashed the convictions. ${ }^{134}$ The judges' observations demonstrate the difficulty of reconciling the need to protect victims of trafficking and the duty to prosecute 'modern slavery' offences in line with the UK's international obligations. ${ }^{135}$ According to the Court of Appeal, 'it is in the public interest to prosecute' when the crime committed is 'grave', regardless of whether the defendant is a victim of human trafficking. ${ }^{136}$ The Court, by refusing or dismissing four out of six appeals, arguably favoured the criminalisation of victims rather than protect them. ${ }^{137}$

131 Laird (n 128); Edwards (n 128) 895.

132 Prison Reform Trust, 'Still No Way Out: Foreign National Women and Trafficked Women in the Criminal Justice System' (Prison Reform Trust and Hibiscus Initiatives 2018) para 2.2 <www.prisonreformtrust.org.uk/Portals/0/Documents/Still\%20No\%20Way $\% 20$ Out $\% 20$ full\%20report.pdf> accessed 16 December 2019; see also S Bird and P Southwell, 'Does the New "Slavery" Defence Offer Victims of Trafficking Any Greater Protection?' (2015) 9 Archbold Review 7; S Mennim, 'Case Comment - The Wrong Side of the Line? Trafficking Victims Compelled to Commit Offences and Prosecutorial Discretion' (2019) 83 Journal of Criminal Law 111.

133 R v Joseph (Verna Sermanfure) [2017] EWCA Crim 36.

134 ibid at paras 136 and 160.

135 ibid at para 28.

136 ibid at para 31.

137 See ibid at paras 68, 100, 125, 145. 
Another case is $R v G S .{ }^{138}$ GS is a Jamaican national who was sentenced in 2007 to seven years' imprisonment for a drug-related offence. She is also a victim of human trafficking, whose status was confirmed by the Home Office. In 2017, GS applied for an extension of time for leave to appeal against conviction claiming it had been an abuse of process for her trial to proceed. The Court of Appeal acknowledged the material change concerning the treatment of victims between 2007 and after the MSA. ${ }^{139}$ Nonetheless, Lord Justice Gross refused the application, arguing that victims of trafficking are not exempted from prosecution should the latter be in the public interest, and that this is fully in line with the UK's international obligations. ${ }^{140}$ He said: ‘[A]s repeatedly made clear, where crimes have been committed by [victims of human trafficking], even arising from their own trafficking, there is no blanket immunity'. ${ }^{141}$ The prosecutor, the judge continued, has a wide discretion to decide whether to proceed against a victim of trafficking. ${ }^{142}$ According to Lord Justice Gross, GS’s conviction was not unsafe, given that she had committed a 'serious offence' whose 'gravity should not be minimised'. ${ }^{143}$

From the cases above, it is clear that the statutory defence in section 45 of the MSA does not afford victims any significant protection. ${ }^{144}$ In fact, it prioritises prosecution over protection. ${ }^{145}$ Nonetheless, the

$138 \mathrm{R} v$ GS [2018] EWCA Crim 1824.

139 ibid at 64.

$140 \quad$ ibid at para 76.

141 ibid at para 1.

142 ibid at para 76.

143 ibid at paras 78-80.

144 For another case on the lines of Verna Sermanfure and GS, see R v EK [2018] EWCA Crim 2961.

145 The major interest in conviction rather than the welfare of victims also emerges from the fact that the government rejected proposals to introduce an adequate civil remedy for those affected by 'modern slavery'. In $A$ and $B v C I C A$ and Secretary State for Justice [2018] EWCA Civ 1534, Lord Justice Gross observed in passing that '[i]t is by no means inevitable' that Article 4 ECHR 'leaps to the provision of state compensation' in addition to the requirement to prevent trafficking, prosecute offenders and protect victims [at para 66]. 
British government can take advantage of the rhetoric surrounding the new defence to assert its position as a human rights champion. ${ }^{146}$

\section{Risks and preventive orders}

Third, the MSA introduces civil preventive orders to restrict the activity of individuals who pose a risk of committing 'modern slavery' offences. First, courts can grant Prevention Orders against individuals convicted under the MSA or not guilty by reason of insanity who are still at risk of offending. ${ }^{147}$ Second, courts can issue Risk Orders on the basis of a generic risk that a person will exploit another one. ${ }^{148}$ The issuance of these orders is highly discretionary even when the required criteria are met. Should an order be granted, the person concerned will be prohibited from doing anything described in it. ${ }^{149}$ Apart from time limits, there are no specific constraints on the severity of orders, which can have a substantial impact on the recipient. Failure to comply, without reasonable excuse, with any of the prohibitions or requirements imposed by such an order is considered a criminal offence. ${ }^{150}$ Until March 2019, courts in England and Wales adopted 119 Prevention Orders and 46 Risk Orders. ${ }^{151}$ In two cases, the recipients

146 Home Office, 'Historic Law to End Modern Slavery Passed' (n 107).

147 MSA, s 14.

148 ibid s 21.

149 ibid s 17(1) and 24(1).

$150 \quad$ ibid s 30.

151 HM Government, '2019 UK Annual Report on Modern Slavery' (2019) para 2.63 <https://assets.publishing.service.gov.uk/government/uploads/system/uploads/attachment_data/file/840059/Mo dern_Slavery_Report_2019.pdf > accessed 16 December 2019. 
breached one of the conditions in their orders and were sentenced to three and a half and two years and four months in prison, respectively. ${ }^{152}$

While Prevention Orders are contingent upon individuals having already committed a 'modern slavery' offence, Risk Orders are to be seen as pre-emptive steps based on suspicious events. ${ }^{153}$ Their introduction finds validation in the jurisprudence of the ECtHR, which requires states to take preventive measures to protect individuals from harm by others. ${ }^{154}$ The British government explicitly invoked these positive duties in a memorandum prepared by the Home Office in June 2014 to address the compatibility of the then Modern Slavery Bill with the ECHR. ${ }^{155}$ However, the asserted necessity of intervening preventively is also used as a leverage to expand the state's power to coerce and control. ${ }^{156}$ Prevention and Risk Orders may impose harsh coercive measures that are not dissimilar to actual punishment before a harm occurs. The content of the prohibitions is also decided following civil rules of evidence and not the more rigorous criminal ones. ${ }^{157}$ A custodial sentence may also be imposed if the conditions of the orders are breached. With the excuse of providing more security, these orders ultimately afford law enforcement a

152 HM Government, '2018 UK Annual Report on Modern Slavery' (2018) para 2.76 <https://assets.publishing.service.gov.uk/government/uploads/system/uploads/attachment_data/file/749346/ 2018_UK_Annual_Report_on_Modern_Slavery.pdf> accessed 16 December 2019.

153 Worden (n 86) 716.

154 Osman v the United Kingdom (2000) 29 EHRR 245, para 115; Branko Tomašic and Others v Croatia App No $46598 / 06$ (ECtHR, 19 January 2009) para 50. On the relationship between preventive orders and human rights, see JW Nickel, 'Restraining Orders, Liberty, and Due Process' in A Ashworth, L Zedner and P Tomlin (eds), Prevention and the Limits of the Criminal Law (Oxford University Press 2013); Ramsay (n 28) ch 6.

155 Home Office, 'Modern Slavery Bill: European Convention On Human Rights: United Nations Convention On The Rights Of The Child: Memorandum By The Home Office' (n 88) para 28, citing Stubbings and Others v United Kingdom (1997) 23 EHRR 213.

156 For a critical account of the 'turn to preventive measures' in the name of public security in some Western states, see A Ashworth and L Zedner, Preventive Justice (University Press 2014). See also Liora Lazarus' chapter in this volume. 
high degree of flexibility in controlling and limiting individuals' liberties. In so doing, they reinforce the punitive stance of the MSA.

\section{Supporting a culture of conviction}

The MSA plays a crucial role within the UK's strategy to combat crime. The National Audit Office's report Reducing Modern Slavery, published in December 2017, devotes a great deal of space to the increase in recorded crimes, number of investigations, as well as rates of prosecutions and convictions. ${ }^{158}$ The focus is on efficiency and crime reduction. This approach has been endorsed by commentators, who now assess the success (or lack thereof) of the British policy on human trafficking by relying on the quantity of criminal trials that have been carried out. ${ }^{159}$ They decry the (relatively) small number of prosecutions and convictions as they were the main way to assess the UK's effort to fight 'modern slavery'. ${ }^{160}$ However, through such an insistence on criminal accountability, the MSA ultimately reveals a tendency toward those punitive trends that characterise contemporary democracies and have raised criticism among activists and scholars. The MSA shows uncritical reliance on criminal sanctions, a leaning toward long custodial sentences and an extension of preventive police powers. It also combines welfare services and punitive strategies to regulate and exclude those on the margins, such as migrants, sex workers and people from the poorer classes. A great emphasis on prevention, harm reduction and victims' protection is used as a justification for larger criminal justice institutions and increased power to state officials. Finally, the MSA promotes partnerships between corporations, NGOs and individual citizens on the one hand, and the

158 National Audit Office, 'Reducing Modern Slavery’ (Home Office 2017) HC 630 Session 2017-2019.

159 Mantouvalou (n 88) 1026. In her article, Virginia Montouvalou argues that, given the low level of prosecutions, the MSA has failed to meet its purpose. Although she welcomes the criminalisation of human trafficking, she acknowledges that the reason why the British policy on 'modern slavery' is not a success is also because the government still creates structures of exploitation, while pretending to be very serious about tackling the particular wrong.

160 See also National Audit Office (n 158) para 4 (observing that prosecution and conviction rates of 'modern slavery' crimes are still very low). 
state on the other hand, 'in order to help reduce criminal opportunities and enhance crime control'. ${ }^{161}$ This punitive tendency is worrisome because the UK is already heading toward a more repressive penality, with large-scale incarceration, severe punishment and proactive policing strategies. ${ }^{162}$

Some elements of this penal expansion are to be linked to the jurisprudence on coercive human rights. Of course, beyond the requirements of human rights law, there are various interests and rationales that play a role in the criminalisation of human trafficking. The ECtHR can hardly be considered the main reason behind the UK's approach to 'modern slavery' and its narrow focus on criminal justice responses. However, the contribution of human rights in facilitating criminal justice responses cannot be overlooked. The ECtHR's insistence on effective criminal enforcement motivates policing and prosecutorial responses rather than efforts to understand and deal with situations of systemic injustice, in which global inequality, immigration controls and exploitative labour conditions all play a part. ${ }^{163}$ Coercive human rights obligations support and strengthen the MSA's crime control machinery, whilst deflecting attention, energy and resources from initiatives in the opposite direction. The ECtHR promotes an individualistic approach whereby social issues can be solved by tackling single acts of abuse and violence. As a matter of fact, this attitude tends to disregard alternative, noncriminal responses to 'modern slavery', such as inclusive immigration policies or labour regulation. ${ }^{164}$ By the same token, the Act marginalises calls for criminal justice reforms aimed at reducing custodial sentences or decriminalising less serious infractions. Even accepting that human rights-driven criminalisation has not directly increased the net of social control, it has nonetheless normalised criminal law as the default

161 Ward and Fouladvand (n 129), mentioning; Garland, The Culture of Control (n 9) 126.

162 See, eg, Garland, The Culture of Control (n 9).

163 J Christman, 'Human Rights and Global Wrongs' in Diana Tietjens Meyers (ed), Poverty, Agency, and Human Rights (Oxford University Press 2014) 323.

164 Similarly, A Gruber, AJ Cohen and K Mogulescu, 'Penal Welfare and the New Human Trafficking Intervention Courts' (2016) 68 Florida Law Review 1333, 1379 and 1380; C Costello, 'Migrants and Forced Labour: A Labour Law Response' in Alan Bogg and others (eds), Autonomy of Labour Law (Hart Publishing 2015) 191. 
answer to human trafficking, whilst limiting any room for change. While the ECtHR might not be the direct cause of a statute centred on 'crime' rather than on victim protection and structural causes of exploitation, its jurisprudence has sustained this approach by providing a human rights rationale for crime-control measures. The confidence shown by the ECtHR in calling for criminalisation, prosecution and punishment has given criminal law a new legitimacy as the 'sharp edge of the sword' of human rights. ${ }^{165}$ It has also favoured the illusion that criminal management is the answer to problems that are commonly acknowledged as complex and multifaceted. Coercive human rights, when transposed at the domestic level, confer power to the state in pursuing punitive agendas by invoking better protection for victims and compliance with international obligations. At the same time, they neutralise critique about the current conditions of imprisonment or the current policing of borders. ${ }^{166}$ Harsh prison sentences, greater power to prosecute and convict, and extensive pre-emptive measures become acceptable and even desirable when advanced in the name of human rights. ${ }^{167}$ The 'culture of conviction' spreads out and gathers strength.

\section{Conclusion}

It is often argued that the ECtHR is partly responsible for constraining European states' penal policies and supporting a more 'humane' criminal law. While this may in fact be true, the Court has also contributed to sustaining certain punitive impulses, through its coercive human rights obligations. When the ECtHR orders states to resort to criminal law, human rights protection is advanced to bolster penality.

165 RK Woetzel, 'International Criminal Law and Human Rights: The Sharp Edge of the Sword' (1968) 62 Proceedings of the American Society of International Law 117.

166 E Stanley, 'Human Rights as a Protective Force' in L Weber, E Fishwick and M Marmo (eds), The Routledge International Handbook of Criminology and Human Rights (Routledge 2017) 508.

167 D Otto, 'Decoding Crisis in International Law: A Queer Feminist Perspective' in B Stark (ed), International Law and Its Discontents: Confronting Crises (Cambridge University Press) 121. 
However, the European judges have generally failed to ponder the potential pitfalls of their jurisprudence. They have shown a sort of 'criminal fetishism', which overlooks the risks associated with penal expansion and underestimates the fact that criminal law always poses a threat to the individual's freedoms. ${ }^{168}$ Even in cases of abuses of a certain gravity, uncritical reliance on criminal law instruments is problematic if it disregards crucial considerations on the opportunity and implications of deploying penal measures. As the case of the MSA has illustrated, national reforms led by coercive human rights turn out to extend and give legitimacy to forms of penal control, while failing to tackle the root causes of abuses and protect victims.

In conclusion, coercive human rights obligations appear to have a dual function: they require new penal intervention, but they also legitimise punitiveness by covering it up with a humane veil. While activists and scholars have generally condemned the expansion of penality led by 'law and order' rhetoric, such expansion is instead demanded when criminal law is used in the name of human rights. The same individuals who criticise harsh prison conditions and overcriminalisation in the context of counterterrorism or 'tough on crime' policies, are often advocates of extensive penal control to stop human trafficking, protect the right to life and prohibit torture. ${ }^{169}$ By endorsing criminal accountability as the best instrument to protect human rights, the ECtHR has given strength to this form of cognitive dissonance, which, depending on the case, sees penality as problematic or benevolent. But it has also offered European states a new excuse to have recourse to ever more expansive criminal law with little criticism and in a way that seems consistent with progressive thinking.

168 Similarly, in the context of International Criminal Law, D Zolo, 'The Lords of Peace - From the Holy Alliance to the New International Criminal Tribunals' in H Barry (ed), Global Democracy: Key Debates (Routledge 1999) 81-82.

169 For some examples of how various international institutions and NGOs support the expansions of penality in some areas, whilst criticising criminalisation and punishment in others, see A Sattar, Criminal Punishment and Human Rights: Convenient Morality (Routledge 2019) 194-200. 